\title{
Weaning results of beef Hungarian Fleckvieh calves 2. Genetic parameters, breeding values
}

\author{
SZABOLCS BENE, IMRE FÜLLER, ATTILA FÖRDŐS and FERENC SZABÓ
}

Georgikon Faculty, University of Pannonia, Keszthely, Hungary

\begin{abstract}
Weaning weight, preweaning daily gain and 205-day weight of Hungarian Fleckvieh calves ( $n=8929$, bulls $=4539$, heifers =4 390) born from 232 sires between 1980 and 2003 were examined. Variance, covariance components and heritability values and correlation coefficients were estimated. The effect of the maternal permanent environment on genetic parameters and breeding values were examined. Two animal models were used for breeding value estimation. The direct heritability $\left(h_{d}^{2}\right)$ of weaning weight, preweaning daily gain and 205-day weight was between 0.37 and 0.42 . The maternal heritability $\left(\mathrm{h}_{\mathrm{m}}^{2}\right)$ of these traits was 0.06 and 0.07 . The direct-maternal correlations $\left(r_{\mathrm{dm}}\right)$ were medium and negative -0.52 and -0.74 . Contribution of the maternal heritability and maternal permanent environment to phenotype is smaller than that of direct heritabilities $\left(h_{m}^{2}+c^{2}<h_{d}^{2}\right)$. The ratio of the variance of maternal permanent environment in the phenotypic variance $\left(c^{2}\right)$ changed from 3 to $6 \%$. Estimated breeding values changed whether the permanent environmental effect of dam wasn't taken into consideration but the rank of the animals was not modified. The genetic value for weaning results of Hungarian Fleckvieh population has increased since 1997.
\end{abstract}

Keywords: beef cattle, weaning weight, variance, heritability, breeding value, Hungarian Fleckvieh

\section{Zusammenfassung}

\section{Absetzergebnisse ungarischer Fleckviehkälber \\ 2. Genetische Parameter und Zuchtwerte}

Ausgewertet wurde das Absetzgewicht, die tägliche Zunahme bis zum Absetzen und das 205-Tage Gewicht von 9829 ungarischen Fleckviehkälbern (4 539 männliche und 4390 weibliche) geboren zwischen 1980 und 2003 als Nachkommen von 232 Fleckviehbullen. Berechnet bzw. geschätzt wurden Varianz- und Kovarianzkomponenten, Heritabilitätswerte, Korrelationskoeffizienten, der ständige Umwelteffekt der Mutter auf die genetischen Parameter und Zuchtwerte. Die Parameterschätzung erfolgte mit dem Tiermodell 1 und 2. Die direkte Heritabilität $\left(h_{d}^{2}\right)$ für die drei Merkmale Absetzgewicht, tägliche Zunahme bis zum Absetzen und 205-Tage Gewicht erreichte mittlere Werte zwischen 0,37 und 0,45 und die maternalen Heritabilitätswerte $\left(\mathrm{h}_{\mathrm{m}}^{2}\right)$ waren mit 0,06 und 0,07 niedrig. Negativ waren die Korrelationskoeffizienten zwischen den direkten und maternalen genetischen Effekten $\left(r_{d m}\right)$; sie lagen bei $-0,52$ und $-0,74$. Der maternale 
genetische Effekt und der maternale ständige Umwelteffekt hat den Phänotyp geringer als der direkte genetische Effekt beeinflusst $\left(h_{m}^{2}+c^{2}<h_{d}^{2}\right)$. Das Verhältnis des ständigen maternalen Umwelteffektes zum Phänotyp $\left(c^{2}\right)$ veränderte sich zwischen 3 und $6 \%$. Die Berücksichtigung dieses Effektes im Modell oder die Nichtbeachtung des Modells haben den Effekt des ständigen maternalen Umwelteffektes auf den genetischen Effekt zwar beeinflusst aber die Rangordnung der Bullen nicht geändert. In den untersuchten zwei ungarischen Fleckviehbetrieben konnte ab 1997 eine Verbesserung der Zuchtwerte bezüglich der Kälberabsetzergebnisse beobachtet werden.

Schlüsselwörter: Fleischrind, Absetzgewicht, Variance, Heritabilität, Zuchtwert, Ungarisches Fleckvieh

\section{Introduction}

The efficiency of beef cattle, resp. slaughter cattle production can be considerably influenced by the weaning weight of calves in the Hungarian Fleckvieh farms, too. Therefore the evaluation of these traits and the estimation their genetic parameters are very important. From these parameters the value of heritability is important, which is the ratio of total phenotypic variance of a given trait, which can be ascribed to the genetic variance.

The heritability is typically of a population kept in a certain region, therefore if we want to make a breeding program for a breed we have to calculate it for the given population and environment. Besides, the environment the heritability of a given trait is influenced by the height of genetic variance. It considerably depends on the sire, the relatives and the grade of inbreeding.

The heritability value $\left(\mathrm{h}^{2}\right)$ depends on the method of calculation, too. The ways of evaluation take apart the diverse variance components with a different exactness whereby the residual variance can be lower or higher.

There are numerous references on the genetic parameters of weaning traits both in the national and the international literature (WOLLERT et al. 1989, KRESS et al. 1990, MEYER et al. 1991, VAN VLECK et al. 1992, SPLAN et al. 1998, 2002, SZŐKE and KOMLÓSI, 2000, ALBUQUERQUE and MEYER 2001, JAKUBEC et al. 2003, LENGYEL et al. 2003, 2004, IWAISAKI et al. 2005, ROSO et al. 2005, RILEY et al. 2007, VOSTRY et al. 2007).

The Table 1 shows the heritability values of gain and weaning weight at Simmental breed. These results were found by some researchers. The table includes the name of author(s), breed, and country, method of estimating and direct and maternal heritability of traits.

At present the connection between maternal and genetic effects is of the mentioned in the foreign literature. The (co)variance, resp. correlation between the two effects has different degrees and senses.

Having examined the weaning weight of Angus population MEYER (1992) found the correlation between the direct and maternal genetic effect 0.22 . In their examinations NÚNEZ-DOMINGUEZ et al. (1993) found in Angus and Hereford populations the value of correlation in case of weaning weight 0.25 and 0.63 respectively. VAN VLECK et al. (1996) examined the correlation between the direct and the maternal genetic effect in Charolais, Simmental, Red Poll and Braunvieh population. As a result they got a correlation 0.46, $0.16,0.31$ and 0.25 respectively. CUBAS et al. (1991) found a correlation -0.93 between 
the two effects in an Angus population. DODENHOFF et al. (1999) report on a correlation value $-0.12,-0.37,-0.18$, and -0.10 respectively in case of weaning weight in Charolais, Hereford, Limousin, and Simmental population.

Table 1

Heritability values of gain and weaning weight

Die Heritabilität der Zunahme und des Absetzgewichts

\begin{tabular}{llccccc}
\hline Source & Trait & Breed & Country & Model & $\mathrm{h}_{\mathrm{d}}^{2}$ & $\mathrm{~h}_{\mathrm{m}}^{2}$ \\
\hline DODENHOFF et al. (1999) & WW & Simmental & USA & $\mathrm{E}$ & 0.22 & 0.25 \\
LEE et al. (1997a) & WW & Simmental & USA & $\mathrm{E}$ & 0.21 & 0.10 \\
LEE et al. (1997b) & WW & Simmental & USA & $\mathrm{E}$ & 0.21 & 0.09 \\
MARQUES et al. (2000) & WW & Simmental & Brazil & $\mathrm{E}$ & 0.13 & 0.13 \\
TRUS and WILTON (1988) & PDG & Simmental & Canada & S-MGS & 0.43 & 0.20 \\
VAN VLECK et al. (1996) & WW & Simmental & USA & $\mathrm{E}$ & 0.23 & 0.23 \\
\hline
\end{tabular}

WW weaning weight, PDG preweaning daily gain, E animal model, S-MGS sire-maternal grandsire model, $h_{d}^{2}$ direct heritability, $h_{m}^{2}$ maternal heritability

The effect of permanent environmental variance of dam in the phenotype can be different sized. The value of it was found by CARNIER et al. (2000), DUANGJINDA et al. (2001), LEE et al. (1997b), MEYER (1992), NÚNEZ-DOMINGUEZ et al. (1993), VAN VLECK et al. (1996) between 0 and 10\%. DUANGJINDA et al. (2001) found a value between 14-17\% in case of weaning weight in Gelbvieh and Charolais population; ELER et al. (1995) found $14 \%$ in a Nelore population. Having examined the contribute of the permanent environmental effect of dam to the phenotype found MEYER et al. (1993) in case of the weaning weight in Hereford and Wokalup population $20 \%$ and $12 \%$ respectively. In another work of his found it MEYER (1992) in a Hereford and Zebu cross-bred population $23 \%$ and $11 \%$ respectively. NÚNEZ-DOMINGUEZ et al. (1993) found it in case of weaning weight in Angus population 11\%, PARIACOTE et al. (1998) in found it in Hereford population $14 \%$. VAN VLECK et al. (1996) estimated in his investigations in Hereford, Limousin, Charolais, Gelbvieh and Red Poll population 29\%, 30\%, 18\%, 21\%, 12\% and $17 \%$ respectively.

The aim of the present investigation was to estimate the variance, (co)variance components and genetic parameters of weaning weight, preweaning daily gain and 205day weight by the means of two animal models in two Hungarian Fleckvieh populations. Furthermore the aim was to make a comparison between the two animal models, i.e. to estimate whether the maternal permanent environmental effect has an influence on the genetic parameters and the estimated breeding value of animals. Bedsides, the aim was to know what genetic trend is to be observed in the weaning performances of Hungarian Fleckvieh populations.

\section{Material and methods}

In the present examinations three traits were evaluated: the weaning weight, the preweaning daily gain and the 205-day weight. The evaluation includes the data of 8929 calves ( 4539 bulls and 4390 heifers) of 232 Hungarian Fleckvieh sires born between 1980 and 2003. The data were given by the Association of Hungarian Fleckvieh Breeders. The composition of the examined population is showed in the Table 2. 
Table 2

Composition of the examined population

Zusammensetzung der untersuchten Population

\begin{tabular}{lc}
\hline Designation & Number of animals \\
\hline Number of animals with records & 8929 \\
Sires & 232 \\
Dams & 2057 \\
Paternal grandsires & 17 \\
Maternal grandsires & 114 \\
Total grandsires & 131 \\
Paternal grand dams & 24 \\
Maternal grand dams & 817 \\
Total grand dams & 841 \\
Calve without performance & 1897 \\
\hline
\end{tabular}

The following variance and (co)variance components and genetic parameters have been estimated:

- additive direct genetic variance $\left(\sigma_{d}^{2}\right)$

- maternal genetic variance $\left(\sigma_{m}^{2}\right)$

- direct maternal genetic (co)variance $\left(\sigma_{\mathrm{dm}}\right)$

- maternal permanent environmental effect $\left(\sigma_{\mathrm{pe}}^{2}\right)$

- residual variance $\left(\sigma_{\mathrm{e}}^{2}\right)$

- phenotypic variance $\left(\sigma_{p}^{2}\right)$

- direct heritability $\left(\mathrm{h}_{\mathrm{d}}^{2}\right)$

- maternal heritability $\left(\mathrm{h}_{\mathrm{m}}^{2}\right)$

- total heritability $\left(\mathrm{h}_{\mathrm{T}}^{2}\right)$

- direct maternal genetic correlation $\left(r_{d m}\right)$

- ratio of permanent environmental variance in the phenotypic variance $\left(c^{2}\right)$

- ratio of residual variance in the phenotypic variance $\left(\mathrm{e}^{2}\right)$.

The parameters and breeding values were estimated with animal model. The applied model (model 1 ) was in case of all traits the following:

$$
\mathbf{y}=\mathbf{X b}+\mathbf{Z u}+\mathbf{W} \mathbf{m}+\mathbf{S p e}+\mathbf{e}
$$

where $\mathbf{y}$ is the vector of observation (trait), $\mathbf{b}$ is the vector of fixed effect(s), $\mathbf{u}$ is the vector of random effect (animal), $\mathbf{m}$ is the vector of maternal genetic effect, $\mathbf{p e}$ is the vector of maternal permanent environmental effect, $\mathbf{e}$ is the vector of random residual effect, $\mathbf{X}$ is the matrix of fixed effects, $\mathbf{Z}$ is the matrix of random effects, $\mathbf{W}$ is the matrix of maternal genetic effect, and $\mathbf{S}$ is the matrix of maternal permanent environmental effect.

In the course of evaluation by an animal model the fixed effects were herd, age of dam, year, season and sex. In case of weaning weight and preweaning daily gain the effect of weaning age as (co)variant was taken into consideration, too.

Having examined the maternal permanent environmental effect two models were applied. One of them was an animal model, identical with the above mentioned model, the other animal model (model 2) was different, and it didn't include the maternal permanent environmental effect. 
With the two animal models the effect of maternal permanent environmental effect was analysed on estimated parameters, breeding value of animals and their rank if it is taken into account or if it is left out of consideration. The influence on the rank of animals was determined by calculation of rank correlation.

The genetic trend of weaning results of Hungarian Fleckvieh was stated according to the means of breeding values referring to the year of birth. The animal model estimates a breeding value for each animal (dam, sire, calf). To determine the genetic trend the breeding value of the animal, born in the same year based on the direct genetic effect was averaged and the obtained points were represented in a system of co-ordinates.

The variance and (co)variance components, genetic parameters and breeding value were estimated with the DFREML (MEYER 1998) and MTDFREML (BOLDMAN et al. 1993) programs. For the rank-correlation calculation the SPSS 9.0 (1996) program was applied.

\section{Results and discussion}

The overall mean weaning results are shown by the Table 3 . The mean weaning weight of the Hungarian Fleckvieh calves was $217 \mathrm{~kg}$, the preweaning daily gain $1.009 \mathrm{~kg} /$ day, the 205-day weight $242 \mathrm{~kg}$ and the mean weaning age 181 days.

Table 3

Overall results of weaned calves

Gesamtergebnisse der abgesetzten Kälber

\begin{tabular}{lcccc}
\hline Designation & Weaning weight, kg & $\begin{array}{c}\text { Preweaning daily } \\
\text { gain, kg/day }\end{array}$ & 205-day weight, kg & $\begin{array}{c}\text { Age of calves at } \\
\text { weaning, day }\end{array}$ \\
\hline Overall mean value & 217 & 1.009 & 242 & 181 \\
Standard deviation & 45.30 & 0.198 & 40.46 & 35.53 \\
Coefficient of variation, cv\% & 20.86 & 19.61 & 16.71 & 19.63 \\
Minimum & 100 & 0.327 & 100 & 80 \\
Maximum & 435 & 1.750 & 390 & 301 \\
\hline
\end{tabular}

\section{Variance and (co)variance components, genetic parameters}

The Table 4 includes the variance and (co)variance components and the genetic parameters estimated with the two different animal models (model 1 and model 2).

The table shows that the (co)variance between the direct additive genetic effect and the maternal genetic effect was negative at all the three traits, so the sense of the correlation between the two effects is negative, too. The correlation coefficient, $r_{d m}$ changed between -0.52 and -0.72 , i.e. there is a close negative connection between the two effects, which is similar to the results of VAN VLECK et al. (2002).

The direct heritability of weaning weight, preweaning daily weight and 205-day weight $h_{d}^{2}=0.40,0.42$ and 0.37 respectively, these values are higher, than the results of LENGYEL et al. (2003) $\left(h_{d}^{2}=0.10,0.13\right.$ and 0.14 respectively). The maternal heritability of the examined traits $h_{m}^{2}=$ between 0.06 and 0.07 .

The maternal permanent environmental effect in the phenotype $\left(c^{2}\right)$ is between 3 and $6 \%$. 
Table 4

Genetic parameters, variance and covariance components

Genetische Parameter, Varianz-und (Ko)varianzkomponenten

\begin{tabular}{|c|c|c|c|}
\hline \multicolumn{2}{|c|}{ Parameters } & Model 1 & Model 2 \\
\hline \multicolumn{4}{|c|}{ Weaning weight } \\
\hline$\sigma_{d}^{2}$ & additive direct genetic variance & 388 & 380 \\
\hline$\sigma_{m}^{2}$ & maternal genetic variance & 60 & 79 \\
\hline$\sigma_{\mathrm{dm}}^{2}$ & direct maternal genetic covariance & -109 & -103 \\
\hline$\sigma_{\mathrm{pe}}^{2}$ & maternal permanent environmental effect & 32 & - \\
\hline$\sigma_{\mathrm{e}}^{2}$ & residual variance & 595 & 610 \\
\hline$\sigma_{\mathrm{p}}^{2}$ & phenotypic variance & 966 & 966 \\
\hline$h_{d}^{2}$ & direct heritability & $0.40 \pm 0.06$ & $0.39 \pm 0.06$ \\
\hline$h_{m}^{2}$ & maternal heritability & $0.06 \pm 0.02$ & $0.08 \pm 0.02$ \\
\hline \multirow{2}{*}{$\begin{array}{l}r_{d m} \\
c^{2}\end{array}$} & \multirow{2}{*}{$\begin{array}{l}\text { direct-maternal genetic correlation } \\
\text { the ratio of the permanent environmental variance to the } \\
\text { phenotypic variance }\end{array}$} & $-0.72 \pm 0.10$ & $-0.60 \pm 0.09$ \\
\hline & & $0.03 \pm 0.01$ & - \\
\hline$e^{2}$ & the ratio of the residual variance to the phenotypic variance & $0.62 \pm 0.05$ & $0.63 \pm 0.04$ \\
\hline \multicolumn{2}{|r|}{$h_{m}^{2}+c^{2}$} & 0.093 & - \\
\hline$h_{T}^{2}$ & total heritability & 0.26 & 0.27 \\
\hline \multicolumn{4}{|c|}{ Preweaning daily gain } \\
\hline$\sigma_{d}^{2}$ & additive direct genetic variance & 0.0119 & 0.0116 \\
\hline$\sigma_{\mathrm{m}}^{2}$ & maternal genetic variance & 0.0021 & 0.0029 \\
\hline$\sigma_{\mathrm{dm}}^{2}$ & direct maternal genetic covariance & -0.0036 & 0.0035 \\
\hline$\sigma_{\mathrm{pe}}^{2}$ & maternal permanent environmental effect & 0.0012 & - \\
\hline$\sigma_{\mathrm{e}}^{2}$ & residual variance & 0.0165 & 0.0170 \\
\hline$\sigma_{\mathrm{p}}^{2}$ & phenotypic variance & 0.0281 & 0.0281 \\
\hline$h_{d}^{2}$ & direct heritability & $0.42 \pm 0.06$ & $0.41 \pm 0.06$ \\
\hline$h_{m}^{2}$ & maternal heritability & $0.07 \pm 0.02$ & $0.10 \pm 0.03$ \\
\hline \multirow{2}{*}{$\begin{array}{l}r_{d m} \\
c^{2}\end{array}$} & \multirow{2}{*}{$\begin{array}{l}\text { direct-maternal genetic correlation } \\
\text { the ratio of the permanent environmental variance to the } \\
\text { phenotypic variance }\end{array}$} & $-0.74 \pm 0.09$ & $-0.60 \pm 0.08$ \\
\hline & & $0.04 \pm 0.01$ & - \\
\hline$e^{2}$ & the ratio of the residual variance to the phenotypic variance & $0.59 \pm 0.05$ & $0.61 \pm 0.05$ \\
\hline \multicolumn{2}{|r|}{$h_{m}^{2}+c^{2}$} & 0.114 & - \\
\hline$h_{T}^{2}$ & total heritability & 0.27 & 0.28 \\
\hline \multicolumn{4}{|c|}{ 205-day weight } \\
\hline$\sigma_{d}^{2}$ & additive direct genetic variance & 461 & 451 \\
\hline$\sigma_{\mathrm{m}}^{2}$ & maternal genetic variance & 89 & 145 \\
\hline$\sigma_{\mathrm{dm}}^{2}$ & direct maternal genetic covariance & -137 & -134 \\
\hline$\sigma_{\mathrm{pe}}^{2}$ & maternal permanent environmental effect & 69 & - \\
\hline$\sigma_{\mathrm{e}}^{2}$ & residual variance & 768 & 791 \\
\hline$\sigma_{\mathrm{p}}^{2}$ & phenotypic variance & 1250 & 1253 \\
\hline$h_{d}^{2}$ & direct heritability & $0.37 \pm 0.06$ & $0.36 \pm 0.06$ \\
\hline$h_{m}^{2}$ & maternal heritability & $0.07 \pm 0.03$ & $0.12 \pm 0.03$ \\
\hline \multirow{2}{*}{$\begin{array}{l}r_{d m} \\
c^{2}\end{array}$} & \multirow{2}{*}{$\begin{array}{l}\text { direct-maternal genetic correlation } \\
\text { the ratio of the permanent environmental variance to the } \\
\text { phenotypic variance }\end{array}$} & $-0.68 \pm 0.10$ & $-0.52 \pm 0.09$ \\
\hline & & $0.06 \pm 0.02$ & - \\
\hline$e^{2}$ & the ratio of the residual variance to the phenotypic variance & $0.61 \pm 0.04$ & $0.63 \pm 0.04$ \\
\hline \multicolumn{2}{|c|}{$h_{m}^{2}+c^{2}$} & 0.125 & - \\
\hline$h_{T}^{2}$ & total heritability & 0.24 & 0.27 \\
\hline
\end{tabular}


The maternal genetic effect and the maternal permanent environmental effect are together $\left(h_{m}^{2}+c^{2}\right) 0.09-0.12$, which is lower than the result of LENGYEL et al. (2003) in Limousine populations $(0.15-0.18)$. The total heritability of the examined traits $h_{T}^{2}=0.24$ 0.27 . The residual variance in the phenotype (e2) changed between 0.59 and 0.62 .

\section{Comparison the models}

The results prove that there is a difference between the breeding values estimated by two different models. Therefore it was examined by rank-correlation whether the said difference causes a change in the rank of the animals.

According to the obtained rank-correlation coefficients (Table 5) $(r=0.95,0.94,0.92$; $P<0.01)$ it seems that the rank of animals stated according to their breeding value wasn't influenced by the model in spite of the mentioned significant difference, because there is a close connection between the two ranks.

Table 5

Comparison of the models with rank-correlation

Vergleich der zwei Modelle aufgrund der Rangkorrelation

\begin{tabular}{lcccc} 
& & & Model 1 & CWW \\
\cline { 3 - 5 } & & WW & PDG & - \\
Model 2 & WW & $0.95^{* *}$ & - & - \\
& PDG & - & $0.94^{* *}$ & $0.92^{* *}$ \\
\hline
\end{tabular}

$\overline{W W}$ weaning weight, PDG preweaning daily gain, CCW 205-day weight, ${ }^{* *} P<0.01$

\section{Breeding values}

The Table 6 includes the estimated breeding value of the examined sires according to the additive direct and maternal genetic effect. According to the breeding value estimated on the direct genetic effect the best was the sire No. 12316, whose breeding value was by $+24.0 \mathrm{~kg},+0.15 \mathrm{~kg} /$ day and $+22.2 \mathrm{~kg}$ higher than the mean value of the population. The worst was the breeder bull No. 12565 , whose breeding value was $-51.6 \mathrm{~kg},-0.25 \mathrm{~kg} / \mathrm{day}$ and $-56.3 \mathrm{~kg}$ in the examined traits.

The Table 7 includes the rank-line of sires according to the breeding value estimated on the direct maternal effect, taking the two different models into consideration. It can be laid down that the sires whose breeding values estimated on maternal effect (e.g. No. 6455 and No. 12565) is the best, are the last in the rank-line according to the breeding value estimated on the direct effect, and it is true in the opposite direction too (e.g. 9683, 12316). This can be explained with the mean, resp. close negative correlation $\left(r_{d m}=\right.$ between -0.52 and -0.72 ). The sire No. 10811 can be counted as an exception because it is the 6 th in the rank-line according to the breeding value estimated on the maternal effect, but he is in the middle of the rank-line (11th) according to the breeding value estimated on the direct effect. 
Table 6

Estimated breeding value of the tested sires by animal model Der Zuchtwert der Bullen geschätzt mit Einzelmodell

\begin{tabular}{|c|c|c|c|c|c|c|c|c|c|c|c|c|c|}
\hline \multirow{3}{*}{ ID of sire } & \multirow{3}{*}{$\mathrm{n}$} & \multicolumn{4}{|c|}{ Weaning weight, $\mathrm{kg}$} & \multicolumn{4}{|c|}{ Preweaning daily gain, kg/day } & \multicolumn{4}{|c|}{ 205-day weight, $\mathrm{kg}$} \\
\hline & & \multicolumn{2}{|c|}{ Direct } & \multicolumn{2}{|c|}{ Maternal } & \multicolumn{2}{|c|}{ Direct } & \multicolumn{2}{|c|}{ Maternal } & \multicolumn{2}{|c|}{ Direct } & \multicolumn{2}{|c|}{ Maternal } \\
\hline & & M1 & M2 & M1 & M2 & M1 & M2 & M1 & M2 & M1 & M2 & M1 & M2 \\
\hline 5385 & 537 & -3.0 & -2.9 & -6.0 & -9.3 & 0.00 & 0.00 & -0.05 & -0.07 & -3.4 & -3.2 & -9.3 & -16.1 \\
\hline 6276 & 151 & 6.0 & 5.8 & 0.7 & 1.6 & 0.04 & 0.04 & 0.00 & 0.00 & 12.3 & 12.1 & -0.7 & 0.6 \\
\hline 6455 & 319 & -12.6 & -12.4 & 7.2 & 8.6 & -0.07 & -0.07 & 0.04 & 0.04 & -13.5 & -13.2 & 6.9 & 8.4 \\
\hline 7231 & 151 & -7.0 & -6.9 & -1.1 & -2.6 & -0.03 & -0.03 & -0.01 & -0.03 & -11.9 & -11.7 & -1.1 & -4.0 \\
\hline 8246 & 152 & 7.9 & 8.0 & -3.7 & -4.9 & 0.06 & 0.06 & -0.03 & -0.04 & 18.0 & 18.4 & -7.0 & -9.3 \\
\hline 9277 & 138 & -8.2 & -6.1 & -0.5 & -1.9 & -0.03 & -0.02 & 0.00 & -0.01 & -9.3 & -5.5 & -2.0 & -4.7 \\
\hline 9330 & 290 & -3.5 & -3.6 & 1.9 & 2.7 & -0.02 & -0.02 & 0.01 & 0.02 & -7.2 & -7.3 & 3.9 & 5.6 \\
\hline 9683 & 150 & 22.2 & 21.7 & -6.2 & -5.9 & 0.18 & 0.17 & -0.05 & -0.05 & 41.5 & 41.0 & -12.4 & -12.1 \\
\hline 10336 & 170 & 5.6 & 5.6 & -7.5 & -10.4 & 0.04 & 0.04 & -0.05 & -0.07 & 7.0 & 7.1 & -9.7 & -14.5 \\
\hline 10811 & 249 & 0.5 & 0.8 & 0.1 & 0.4 & 0.03 & 0.04 & -0.01 & 0.00 & 14.1 & 14.5 & -4.8 & -5.3 \\
\hline 10812 & 140 & 10.1 & 10.0 & -6.0 & -7.0 & 0.05 & 0.05 & -0.04 & -0.05 & 11.5 & 11.4 & -8.9 & -11.9 \\
\hline 12314 & 127 & 17.4 & 17.4 & -5.6 & -5.8 & 0.12 & 0.12 & -0.05 & -0.05 & 12.1 & 12.0 & -1.1 & 0.0 \\
\hline 12316 & 316 & 24.0 & 24.1 & -13.4 & -14.7 & 0.15 & 0.15 & -0.10 & -0.11 & 22.2 & 22.4 & -12.6 & -13.9 \\
\hline 12565 & 206 & -51.6 & -51.9 & 18.4 & 19.2 & -0.25 & -0.25 & 0.09 & 0.09 & -56.3 & -56.8 & 21.4 & 22.9 \\
\hline 12928 & 190 & 10.5 & 10.5 & -2.0 & -1.7 & 0.06 & 0.06 & -0.02 & -0.02 & 7.6 & 7.6 & -0.6 & 0.4 \\
\hline 12930 & 169 & -21.5 & -21.6 & 2.5 & 1.0 & -0.14 & -0.14 & 0.03 & 0.02 & -23.5 & -23.4 & 1.6 & -1.0 \\
\hline 14180 & 139 & -14.5 & -14.4 & 1.7 & 0.0 & -0.07 & -0.07 & 0.02 & 0.01 & -15.1 & -14.7 & 0.9 & -2.4 \\
\hline 14588 & 331 & 3.3 & 3.3 & -3.9 & -5.1 & 0.03 & 0.03 & -0.02 & -0.02 & 13.2 & 13.1 & -7.8 & -9.4 \\
\hline 14595 & 183 & -1.7 & -1.6 & 0.2 & 0.0 & -0.02 & -0.02 & 0.00 & 0.00 & -4.0 & -3.6 & 1.2 & 1.1 \\
\hline 15655 & 148 & 9.1 & 9.6 & -2.6 & -2.7 & 0.09 & 0.10 & -0.03 & -0.03 & 10.8 & 11.7 & -3.5 & -4.0 \\
\hline
\end{tabular}

M1 model 1, M2 model 2

Table 7

The rank-line of sires

Die Rangordnung der Bullen

\begin{tabular}{|c|c|c|c|c|c|c|c|c|c|c|c|c|}
\hline \multirow{3}{*}{ ID of sire } & \multicolumn{4}{|c|}{ Weaning weight, kg } & \multicolumn{4}{|c|}{ Preweaning daily weight, $\mathrm{kg} /$ day } & \multicolumn{4}{|c|}{ 205-day weight, kg } \\
\hline & \multicolumn{2}{|c|}{ Direct } & \multicolumn{2}{|c|}{ Maternal } & \multicolumn{2}{|c|}{ Direct } & \multicolumn{2}{|c|}{ Maternal } & \multicolumn{2}{|c|}{ Direct } & \multicolumn{2}{|c|}{ Maternal } \\
\hline & M1 & M2 & M1 & M2 & M1 & M2 & M1 & M2 & M1 & M2 & M1 & M2 \\
\hline 12316 & 1 & 1 & 20 & 20 & 2 & 2 & 20 & 20 & 2 & 2 & 20 & 18 \\
\hline 9683 & 2 & 2 & 18 & 16 & 1 & 1 & 16 & 16 & 1 & 1 & 19 & 17 \\
\hline 12314 & 3 & 3 & 15 & 15 & 3 & 3 & 17 & 17 & 7 & 7 & 9 & 7 \\
\hline 12928 & 4 & 4 & 11 & 9 & 5 & 5 & 11 & 10 & 10 & 10 & 7 & 6 \\
\hline 10812 & 5 & 5 & 16 & 17 & 7 & 7 & 15 & 15 & 8 & 9 & 16 & 16 \\
\hline 15655 & 6 & 6 & 12 & 12 & 4 & 4 & 13 & 13 & 9 & 8 & 12 & 11 \\
\hline 8246 & 7 & 7 & 13 & 13 & 6 & 6 & 14 & 14 & 3 & 3 & 14 & 14 \\
\hline 6276 & 8 & 8 & 6 & 4 & 8 & 8 & 6 & 6 & 6 & 6 & 8 & 5 \\
\hline 10336 & 9 & 9 & 19 & 19 & 9 & 9 & 18 & 18 & 11 & 11 & 18 & 19 \\
\hline 14588 & 10 & 10 & 14 & 14 & 11 & 11 & 12 & 11 & 5 & 5 & 15 & 15 \\
\hline 10811 & 11 & 11 & 8 & 6 & 10 & 10 & 9 & 8 & 4 & 4 & 13 & 13 \\
\hline 14595 & 12 & 12 & 7 & 8 & 14 & 14 & 7 & 7 & 13 & 13 & 5 & 4 \\
\hline 5385 & 13 & 13 & 17 & 18 & 12 & 12 & 19 & 19 & 12 & 12 & 17 & 20 \\
\hline 9330 & 14 & 14 & 4 & 3 & 13 & 13 & 5 & 4 & 14 & 15 & 3 & 3 \\
\hline 7231 & 15 & 16 & 10 & 11 & 16 & 16 & 10 & 12 & 16 & 16 & 10 & 10 \\
\hline 9277 & 16 & 15 & 9 & 10 & 15 & 15 & 8 & 9 & 15 & 14 & 11 & 12 \\
\hline 6455 & 17 & 17 & 2 & 2 & 17 & 17 & 2 & 2 & 17 & 17 & 2 & 2 \\
\hline 14180 & 18 & 18 & 5 & 7 & 18 & 18 & 4 & 5 & 18 & 18 & 6 & 9 \\
\hline 12930 & 19 & 19 & 3 & 5 & 19 & 19 & 3 & 3 & 19 & 19 & 4 & 8 \\
\hline 12565 & 20 & 20 & 1 & 1 & 20 & 20 & 1 & 1 & 20 & 20 & 1 & 1 \\
\hline
\end{tabular}

M1 model 1, M2 model 2 
In the table it can be seen that there is not any considering deviation between the ranklines, established according to the breeding values based on the direct effect.

In the rank line of breeding values estimated on the maternal effect can be found a higher deviation, e.g. the sire No. 12938, which is on the 4th place according to the 205-day weight in the model 1, but he is on the 8th place, when he was estimated by the model 2. It can be observed in case of the sires No. 5385 and 14180 too. In spite of the mentioned differences the rank-correlation in the rank-line of the breeding values estimated on the maternal effect didn't show significant deviation.

According to the obtained results it can be stated that the sire whose breeding values estimated on the maternal effect are good, has similar breeding values according to the preweaning daily gain and 205-day weight (e.g. the sire No. 10812 was 5th in the rankline according to the weaning weight, 7th according to the preweaning daily gain and 8th according to the 205-day weight).

\section{Change of the genetic value of the population (genetic trend)}

The Figure 1 shows the change of the breeding value of the examined population estimated according to the additive direct genetic effect in case of the 205-day weight by years. The decrease in the years 1993-1994 could be caused by the sire No. 12565 (above in the Tables 7 and 8), which had a spoiling influence. From the 316 calves, born in 1994 124 calves descended from it. Calves born in the same year from sire No. 10457, 12929 and 12930, which had a spoiling effect, too and which weren't included in the tables owing to the lower number of calves. Almost $60 \%$ of the calves born in 1994 descended from a sire with lower breeding value. The remaining $40 \%$ of the calves descended from sires with mean breeding value (e.g. No. 12916) and they had a breeding value near 0 . The genetic trend was determined from the mean value of the breeding value of the animals born in the same year, therefore the program estimated lower breeding value for the calves born in 1994 owing to the predomination of sires with low breeding value (e.g. the calf 08099/0016/940 whose breeding value estimated on the 205-day weight was $48.7 \mathrm{~kg}$, but their own 205-day weight was $140 \mathrm{~kg}$ ) and so became the mean value of their breeding value very low.

Summing up the results it can be say that heritability estimated on the additive direct genetic effect $\left(h_{d}^{2}=0.37-0.42\right)$ is medium. The maternal value of heritability of the examined traits is low $\left(\mathrm{h}_{\mathrm{m}}^{2}=0.08-0.12\right)$. The correlation between the direct and the maternal genetic effects is negative $\left(r_{d m}=-0.52-0.74\right)$, therefore it is practical to take in account both effects together.

The ratio of the maternal permanent environmental variance (maternal effect of environmental origin) in the phenotypic variance $\left(c^{2}\right)$ changed between 0.03 and 0.06 . According to the obtained values can it be stated that the maternal permanent environmental effect is at least as important, as the maternal genetic effect. Therefore in the course of examining the weaning performances it is important to take in account the maternal permanent environmental effect, too.

The estimated maternal genetic effect, so the value of the maternal heritability depends on the applied animal model. If the maternal permanent environmental effect isn't taken in account, this effect will appear in the maternal genetic effect and the 
breeding value estimated on the maternal genetic effect will be higher. The breeding value estimated on the maternal genetic effect is influenced by the fact, whether the maternal permanent environmental effect is taken in account or it is left out of consideration, but the rank-line of the animals isn't influenced by it.

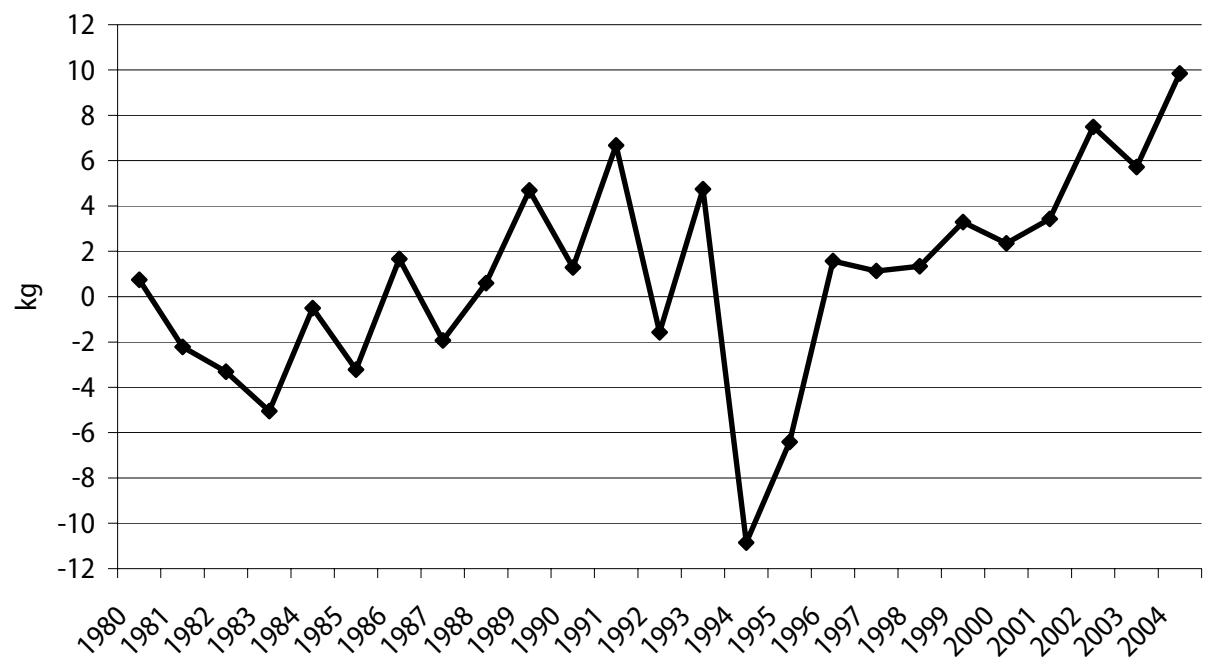

Figure 1

Change of the genetic value of the examined populations in the case of 205-day weight

Änderung des genetischen Trends des 205-Tage Gewichts

\section{References}

Albiquerque LG, Meyer K (2001) Estimates of covariance functions for growth from birth to 630 days of age in Nelore cattle. J Anim Sci 79, 2776-89

Boldman KG, Kriese LA, Van Vleck LD, Kachman SD (1993) A manual for use of MTDFREML. A set of programs to obtain estimates of variances and covariances. USDA-ARS, Clay Center, NE

Carnier P, Albera A, Dal Zotto R, Groen AF, Bona M, Bittante G (2000) Genetic parameters for direct and maternal calving ability over parities in Piedmontese cattle. J Anim Sci 78, 2532-9

Cubas AC, Berger PJ, Healey MH (1991) Genetic parameters for calving ease and survival at birth in Angus field data. J Anim Sci 69, 3952-8

Dodenhoff J, Van Vleck LD, Gregory KE (1999) Estimation of direct, maternal and grand maternal genetic effects for weaning weight in several breeds of beef cattle. J Anim Sci 77, 840-5

Duangjinda M, Bertrand JK, Misztal I, Druet T (2001)Estimation of additive and non additive genetic variances in Hereford, Gelbvieh and Charolais by method »R«. J Anim Sci 79, 2997-3001

Eler JP, Van Vleck LD, Ferraz JBS, Lobo RB Estimation of variances due to direct and maternal effects for growth traits of Nelore cattle. J Anim Sci 73, 3253-8

Gregory KE, Cundiff LV, Koch RM (1992) Breed effects and heterosis in advanced generations of composite populations for reproduction and maternal traits of beef cattle. J Anim Sci 70, 656-72

Iwaisaki H, Tsuruta S, Misztal I, Bertrand JK (2005) Estimation of correlation between maternal permanent environmental effects of related dams in beef cattle. J Anim Sci 83, 537-42

Jakubec V, Scholte W, Riha J, Majzlik I (2003) Comparsin of growth traits of eight beef cattle breeds in the Czech Republic. Arch Tierz 46, 143-53

Kress DD, Doombos DE, Anderson DC (1990) Performance of crosses among Hereford, Angus and Simmental cattle with different levels of Simmental breeding. IV. Matrenal heterosis and calf production by two-year-old dams. J Anim Sci 68, 54-63 
Lee C, Pollak EJ (1997a) Relationship between sire x year interactions and direct-maternal genetic correlation for weaning weight of Simmental Cattle. J Anim Sci 75, 68-75

Lee C, Van Tassel CP, Pollak EJ (1997b) Estimation of genetic variance and covariance components for weaning weight in Simmental cattle. J Anim Sci 75, 325-30

Lengyel Z, Komlósi I, Balika S, Major T, Erdei I, Szabó F (2003) Reproduction and weaning results of Hungarian Limousin populations. 1. Sire model. Hung J Anim Prod 52, 25-38 [in Hungarian]

Lengyel Z, Balika S, Polgár JP, Szabó F (2004) Reproduction and weaning results of Hungarian Limousin populations. 2. Comparison of sire and animal model. Hung J Anim Prod 53, 199-211 [in Hungarian]

Marques LFA, Pereira JCC, Oliveira HN, Silva MA, Bergmann JAG (2000) Analyses of growth traits in Simmental breed in Brazil. Arq Bras Med Vet Zootec 52, 527-33

Meyer K, Hammond K, Mackinnon MJ, Pamel PF (1991) Estimates of covariances between reproduction and growth in Australian beef cattle. J Anim Sci 69, 3533-43

Meyer K (1992) Variance components due tu direct and maternal effects for growth traits of Australian beef cattle. Liv Prod Sci 31, 179-204

Meyer K, Carrick MJ, Donelly BJP (1993) Genetic parameters for growth traits of Australian beef cattle from a multibreed selection experiment. J Anim Sci 71, 2614-22

Meyer K (1998) DFREML. Version 3.0. User Notes

Núnez-Dominguez R, Van Vleck LD, Boldman K, Cundiff LV (1993) Correlations for genetic expression for growth of calves of Hereford and Angus dams using a multivariate animal model. J Anim Sci 71, 2330-40

Paraicote F, Van Vleck LD, Macneil MD (1998) Effects of Inbreeding and heterozygosity on preweaning traits in a closed population of Herefords under selection. J Anim Sci 76, 1303-10

Riley DG, Coleman SW, Chase CC, Olson TA, Hammond A (2007) Genetic parameters for body weight, hip height, and the ratio of weight to hip height from random regression analyses of Brahman feedlot cattle. J Anim Sci 85, 42-52

Roso VM, Schenkel FS, Miller SP, Wilton JW (2005) Additive, dominance, and epistatic loss effects on preweaning weight gain of crossbred beef cattle from different Bos taurus breeds. J Anim Sci 83, 1780-7

Splan RK, Cundiff LV, Van Vleck LD (1998) Genetic parameters for sex-specific traits in beef cattle. J Anim Sci 76, 2272-8

Splan RK, Cundiff LV, Dikeman ME, Van Vleck LD (2002) Estimates of parameters between direct and maternal genetic effects for weaning weight and direct genetic effects for carcass traits in crossbred cattle. J Anim Sci 80, 3107-11

Szőke Sz, Komlósi I (2000) Comparison of BLUP models. Hung J Anim Prod 49,231-245 [in Hungarian]

Trus D, Wilton JW (1988) Genetic parameters for maternal traits in beef cattle. Can J Anim Sci 68,119-128

Van Vleck LD, Hakim AF, Cundiff LV, Koch RM, Crouse JD, Boldman KG (1992) Estimated breeding values for meat characteristics of crossbred cattle with animal model. J Anim Sci 70, 363-71

Van Vleck LD, Gregory KE, Benett GL (1996) Direct and maternal covariances by age of dam for weaning weight. J Anim Sci 74,1801-5

Vostry L, Pribyl J, Vesela Z, Jakubec V (2007) Selection of a suitable data set and model for the estimation of genetic parameters of the weaning weight in beef cattle. Arch Tierz 50, 562-74

Wollert J, Tilsch K, Görlich L, Warzecha H, Breitenstein KG (1989) Untersuchungen zur Genauigkeit der Zuchtwertschätzung von Wachstumsmerkmalen bei Fleischrindkühen. Arch Tierz 32, 139-46

Received 9 August 2008, accepted 8 December 2009.

Corresponding author:

FERENC SZABÓ

email: szf@georgikon.hu

Georgikon Faculty, University of Pannonia, Deák Ferenc str. 16. Pf. 71, H-8360 Keszthely, Hungary 